\title{
Strategi Pengelolan Wisata Perdesaan Berbasis Topografi Alam Perbukitan di Desa Pule Kecamatan Pule Kabupaten Trenggalek
}

\author{
Ubaidillah ${ }^{1}$, Nazlia ${ }^{2}$ \\ ${ }^{1}$ Ushuluddin, UIN Sayyid Ali Rahmatullah Tulungagung \\ ${ }^{2}$ Pendidikan Bahasa Inggris, UIN Sayyid Ali Rahmatullah Tulungagung \\ Email: ${ }^{1}$ Ubaidillah830@gmail.com, nazliyaakhbaroh24@gmail.com,
}

\begin{abstract}
Pule village topography is a hilly area that has economic potential if it is managed well. The functions of it are as water absorption and earthquake defense, besides that the hilly area also can be as ecotourism for the alternative strategy of economic enhancement and for ecosystem education. This research-based service aims to empower the community economy and apply the education that is integrated with nature through participatory method related to the goals achieved. The first result, officially opened the ecotourism with the views of Kekep Hills which has an impact on alternative economics, love for the homeland and critical awareness of the domination of power and economy and culture. The second, the forming of community-based tourism (Pokdarwis) as the management of ecotourism. The third, the education that is integrated of nature becomes the educational and fun media. It was created by using ecotourism pattern to grow the awareness of conservation for childhood. On the basis of these results, of course, this service has limitations in terms of development, so it is necessary to assist and increase collaboration between higher education institutions and the government and productive entrepreneurs.
\end{abstract}

Keywords: Village Tourism, Economic Enhancement, Ecotourism.

\section{Pendahuluan}

Meningkatnya bisnis wisata yang beoreintasi pada bisnis untuk kemajuan ekonomi sebenarnya justru menyebabkan kerusakan lingkungan jika tidak dikelola dengan visi yang benar. Alih fungsi hutan, perkebunan, pertanian dan topografi alam perdesaan seringkali terabaikan demi kepentingan ekonomi. Maka pendampingan dan kejelasan hukum perlu untuk melindungi alih fungsi pertanian sebagai ketahaan pangan dan kelelstarian alam.(Budiono, 2019) Padahal orientasi kepentingan ekonomis dan kesenangan idealnya dikembangakan kearah kesadaran konservasi sebagaimana model wisata edukatif alternatif yang memiliki manfaat hayati bagi manusia dan stabilitas ekosistem. Ekowisata yang berbasis pada kearifan lokal seperti keindahan desa dengan beragam topografinya dapat dimaksimalkan untuk kepentingan pendidikan, konservasi dan bisnis. Oleh karena itu, Pengelolaan wisata desa merupakan usaha memajukan ekonomi desa sekaligus kepedulian menjaga kelestarian topografi alam perdesaan.

Hadirnya ekowisata adalah media wisata edukatif yang tentu dapat menguntungkan dari sisi ekonomi maupun pendidikan serta dapat menekan jumlah tenaga kerja urban di daerah perdesaan khususnya di desa Pule. Sebagai contoh studi kasus pengembangan desa wisata di Desa Nglanggeran yang memberikan dampak positif terhadap ekonomi masyarakat lokal.(Hermawan, 2016) Di sisi lain, eberadaan pariwisata berbasis desa adalah upaya membangun semangat nasionalisme dan kelestarian ekosistem pada saat yang bersamaan.

Dari beberapa penulusuran hasil riset 
serupa dalam upaya mewujudkan ekowisata dapat berupa penanaman bibit pohon yang dilakukan dikampung Malagufuk Kabupaten Sorong.(Pattiwael, 2018) Ekowisata mangrove.(Rini, Setyobudiandi, \& Kamal, 2018) Demikian halnya rekayasa kampung tulip sebagai wisata edukatif.(Hermawan, Brahmanto, \& Priyanto, 2018) serta wisata desa berupa pemanfaatan air terjun.(Safii, Fatih, Rosyid, Zamroni, \& Asy'ari, 2020) Berbeda dengan penelitian sebelumnya kegiatan pengabdian riset ini mengupayakan strategi terwujudnya wisata perdesaan yang diarahkan pada tujuan ekonomi dan pendidikan terintegrasi dengan lembaga pendidikan dasar. Usaha tersebut dilakukan di Desa Pule Kecamatan Pule Kabupaten Trenggalek dengan letak geografis diantara $111^{\circ} 24^{\prime}-112^{\circ} 11^{\prime}$ BT dan $7^{\circ} 33^{\prime}-8^{\circ} 34^{\prime}$ LS.

Hampir seluruh penduduknya bercocok tanam sebagai petani dan buruh tani, buruh harian lepas hingga pekerja swasta. Secara topografis Desa ini merupakan desa di daerah tinggi perbukitan yang memiliki lima dusun yaitu Dusun Tirisan, Dusun Krajan, Dusun Gugur, Dusun Depok dan Dusun Bangunsari. Dari hasi obeservasi ketinggian perbukitan sekitar $714 \mathrm{M}$ dari permukaan laut dengan ragam tanaman seperti kelapa, kelapa sawit, kopi, cengkeh, tembakau, jeruk, duren dan empon-empon. Tetapi dari sekian tanaman hasil janggelan adalah yang terbanyak. Ini menjadi bukti bahwa Desa Pule sangat subur dengan potensi topografi perbukitan. Selain itu, potensi kultural yang kuat dalam tradisi gotong royong, hajatan, dan beberapa perayaan hari besar serta ritual keagamaan seperti Yasinan, tahlilan, jamiyah sholawat, dan berbagai aktifitas lain yang sejenis yang dilakukan secara berjamaah. Potensi kultural tersebut sangat relevan dengan pemberdayaan yang bersifat partisipatif.

Di sisi lain, lembaga pendidikan dasar di Desa Pule cukup banyak dan beragam di mana di tahun 2019 tingkat pendidikan didominasi oleh lulusan Sekolah Dasar (SD) dan Sekolah Menengah Pertama (SMP). Dari data yang diperoleh Di Desa Pule terdapat delapam sekolah dasar diantaranya yang ada di Dusun Tirisan yaitu Sekolah Dasar Negeri (SDN) 2 Pule, SDN 6 Pule, dan SDN 8 Pule, dan 12 Taman Kanak-kanak (TK) dan Pendidikan Anak Usia Dini (PAUD) serta 1 sekolah lanjut tingkat pertama yaitu, MTs Nurul Huda. Dalam konteks ekowisata lembaga pendidikan dapat bersinergi dengan memanfaatkan mata pelajaran yang sesuai dengan pendidikan alam hayati semisal Biologi.(Muntasib, 2018) secara factual ragam pendidikan yang hampir di dominasi oleh sekolah menengah ke bawah berpotensi menciptakan keramaian untuk mendorong para pedagang ikut terlibat secara aktif menciptakan satu rekayasa marketing wisata perdesaan alam perbukitan.

Atas dasar kepentingan di atas maka dibuatlah satu pertanyaan bagaimana strategi menciptakan wisata alam berbasis kearifan lokal. Dari pertanyaan tersebut maka ditetapkan beberapa tujuan seperti pengenalan dan promosi wisata lokal dengan pemanfaatan topografi perbukitan, terciptanya sumber pendapatan alternatif bagi warga sekitar dan menumbuhkan kepedulian dan rasa cinta pada desa.

\section{Metode}

Metode partisipatif berupa Participatory Action Research (PAR) digunakan sebagai upaya kolaboratif bersama masyarakat baik di dalam informasi maupun aksi melalui dialog dan musyawarah untuk menemukan formulasi strategi bersama.(Kindon, Pain, \& Kesby, 2007) Strategi partisipatif untuk kepentingan memastikan proses tahapan, data serta kebijakan akan tepat sasaran dan sesuai target capaian serta meminimalisir hambatan yang terjadi. Proses pemberdayaan dilakukan secara seksama mulai dari perencaan, peta potensi 
wisata desa, strategi dan evaluasi disesuaikan dengan konsep konservasi dan pelestarian alam untuk menunjang fungsi alam hayati sebagai paru-paru dunia.(Ardhana, 2018) Langkah tersebut seperti; mengindentifikasi potensi perbukitan yang layak dijadikan wisata perdesaan, menyiapkan strategi pengembangan wisata perdesaan, sosialisasi pengembangan wisata perbukitan, melibatkan pemangku kebijakan seperti Perangkat Desa, Karang Taruna, Kecamatan, Lembaga Pendidikan dan $\mathrm{LMDH}$, pembentukan Pokdarwis, skema ekonomi kreatif disekitar perbukitan dan strategi promosi wisata perdesaan melalui lembaga pendidikan dasar.

\section{Pembahasan}

Sebelum menyampaikan hasil analisis ada baiknya penulis menyampaikan langkahlangkah PAR yang didasarkan pada masalah dilapangan melalui akar pohon masalah melalui table dibawah ini.

Hasil Participatory Action Research

\begin{tabular}{lll}
\hline \multicolumn{1}{c}{ Langkah } & \multicolumn{1}{c}{ Temuan } & \multicolumn{1}{c}{ Tindakan } \\
\hline Masalah & Dominasi & Sosialisasi dan \\
yang ingin & ekonomi & solusi \\
diselesaika & TKI meningkat & masalah \\
$\mathrm{n}$ & berdampak & Upaya \\
& perceraian & pemberdayaa \\
& & $\mathrm{n}$ ekonomi \\
& & rumahan
\end{tabular}

$\begin{array}{lll}\begin{array}{l}\text { Masalah } \\ \text { utama }\end{array} & \begin{array}{l}\text { Dominasi } \\ \text { ekonomi }\end{array} & \text { Diskusi } \\ & \text { bersama } \\ & \text { warga dan } \\ & \text { perangkat } \\ & \text { desa }\end{array}$

Akar Ekonomi non Pendampinga masalah produktif $\mathrm{n}$ ekonomi produktif Penguasan Pemanfaatan distrubisi online shope penjualan Budaya Sosialisasi "nerimo" peluang dan tantangan Sebab Ketergantunga Strategi

\begin{tabular}{ll}
$\mathrm{n}$ & ekonomi \\
& $\begin{array}{l}\text { kreatif desa } \\
\text { wisata }\end{array}$ \\
kolusi interest & Strategi \\
& $\begin{array}{l}\text { paguyuban; } \\
\text { pokdarwis }\end{array}$ \\
Minim & Membangun \\
kreatifitas & kerjasama \\
\hline
\end{tabular}

\section{Gambaran Umum Perekonomian Desa Pule}

Melalui kegiatan survei lapangan dengan merujuk pada Sensus Keluarga berencana dan Keluarga Sejahtera masyarakat desa Pule diperoleh data yang dapat dijadikan pertimbangan pemberdayaan disektor wisata. Tehitung sejak 2017 pada akhir bulan Juni adalah 11290 jiwa, yang terdiri dari laki-laki sejumlah 5736jiwa dan Perempuan berjumlah 5554 jiwa. Sedangkan jumlah Kepala Keluarga kurang lebih sebanyak $4079 \mathrm{KK}$, dengan kategori KK Prasejahtera sebanyak 1474 KK. Sektor mata pencaharian meliputi pertanian, peternakan dan perdagangan. Dari data tersebut strategi pembukaan wisata perdesaan melalui alam perbukitan dapat meningkatkan kesejahteraan ekonomi masyarakat.

Secara ekonomi Berdasarkan data yang kami peroleh dari warga sekitar Dsn. Tirisan Desa Pule Kecamatan Pule Kabupaten Trenggalek, mayoritas penduduk bermata pencaharian sebagai petani baik lahan sawah maupun ladang. Sebagiannya lagi mengadu nasib di perantauan luar pulau jawa, dan sebagian kecil membuka usaha kecil secara mandiri di rumah. Persoalan keuangan menjadi salah satu pusat alasan mereka mengeluh, terutama mereka yang berprofesi sebagai Petani. Terlebih lagi di musim seperti ini, tak ada lagi yang bisa diandalakan dari hasil pertanian karena memang lahan yang mereka punya tidak mampu memberikan keuntungan apapun untuk memenuhi kehidupan sehari-hari.

\section{Refleksi Ekowisata sebagai Informasi Pembukaan Wisata Perdesaan}

Kemunculan wisata edukatif di tahun 80- 
an merupakan bentuk destinasi alternatif yang di dasarkan pada kesadaran bertanggung jawab terhadap lingkungan, bersimpati pada kearifan lokal baik dalam seni dan budaya serta menunjang kesejahteraan masyarakat. Maka tidak heran pengembangan ekowisata merupakan model wisata edukatif yang dikenal sebagai wisata ekologi. Fungsi ekowisata tidak lain untuk menjaga dan merawat alam dan masyarakat dalam bingkai konservasi.

Oleh karena itu, materi ekowisata pada hakekatnya berupa keindahan alam yang alami (nature) baik perkebunan maupun hutan, topografi pegunungan dan perbuitan serta tradisi serta nilai-nilai lokal yang menjadi bagian dari masyarakat itu sendiri. Dengan demikian, konsep ekowisata adalah konsep wisata rakyat yang sebenarnya mampu bermitra dan melindungi tradisi setempat.(Kesuma, 2016) Secara eksistensial cara pandang ini cukup relevan di tengah upaya pembukaan lahan secara serampangan tanpa memperhatikan dampak lingkungan yang ditimbulkan mulai kekeringan hingga bencana banjir.

Perkembangan ekowisata diawal kemunculan kini tidak sekedar perjalanan wisata ke alam tetapi mulai berkembang ke arah pengembangan bisnis sebagai sebuah kegiatan bisnis. Meski demikian, ekowisata memiliki nilai tambah yang tidak sekedar kesenangan tetapi juga pendidikan dan konservasi. Selain nilai tersebut juga terdapat nilai lainnya seperti, kekaguman atau apresiasi, kesadaran fungsi alam, sustainable, kesenangan dan kesejahteraan.(Nazarullail, Hardika, \& Desyanty, 2017) Di sinilah letak perbedaan dasar wisata dengan ekowisata yang memanfaatkan keberadaan alam tanpa eksploitasi, kearifan lokal masyarakat untuk menjaga alam sebagai tempat tinggalnya.

\section{Strategi Sosialisasi Potensi Wisata Alam Perbukitan}

Setelah melakukan kajian lapangan secara mendalam melalui beberapa penelusuran perbukitan di desa Pule bersama beberapa warga setempat terdapat beberapa bukit yang memiiki potensi salah satunya Gunung Kekep. Setelah lokasi ditentukan maka disusunlah beberapa titik potensial yang dapat dijadikan sebagai spot pemandangan, relaksasi dan permainan. Potensi tersebut dipetakan dan dirancang bentuk bangun sebagai tempat wisata dalam acara pertemuan warga bersama pihak desa dan LMDH. Pertemuan tersebut menghasilkan beberapa gagasan mulai soal perizinan, strategi penghijaun dan aneka permainan sebagai fasilitas tempat wisata.

Upaya partisipatif bersama masyarakat dalam menciptakan ruang ekowisata terus dilakukan untuk membangun semangat warga desa dalam membentuk dan memperkuat Lingkar Budaya Desa (LDB) yang telah ada pada masyarakat desa berupa nilai kebersamaan, persaudaraan dan kesadaran.(Sukiyono et al., 2019) Dari starategi tersebut seluruh pihak warga desa khususnya disekitar lokasi gunung kekep setuju dan mendapat restu dari desa serta pihak LMDH sebagai upaya memberdayakan ekonomi warga dan mengurangi ketergantungan pada produksi emponempon dan tenaga urban.

\section{Strategi Wisata Perdesaan dan Konservasi}

Monografi Desa Pule memiliki luas wilayah 1841.403 ha dengan penggunaan pemukiman 111.372 ha, tanah kering 89.392 ha, Sawah 187.780 ha dan Ladang/Tegalan 583.496 ha. Dengan luas di atas desa Pule memiliki potensi yang layak dikembangkan menjadi wisata pededasaan berbasis topografi alam. usaha tersebut diwujudkan dalam Strategi pembukaan wisata perdesaan alam perbukitan dilakukan dengan melibatkan seluruh pihak hingga ketingkat desa dan kecamatan untuk secara resmi membuka tempat wisata alam perbukitan. Di saat bersamaan melakukan kordinasi dengan pedagang di pasar dan asongan untuk berpartisipasi memeriahkan acara pembukaan. Partisipasi instansi yang terkait 
dalam wisata perdesaan bertujuan untuk promosi di satu sisi dan pengakuan di sisi yang lain untuk dapat dikembangkan dan dikelola lebih baik. Pengakuan pemerintah dilevel desa dan kecamatan akan membangun rasa kepercayaan diri masyarakat untuk serius mengembangkan wisata perdesaan yang banyak dan dan berkembang di daerah yang lain.

Penguatan promosi juga dilakukan dengan melibatkan lembaga pendidikan di didesa Pule. Desa Pule memiliki 8 Sekolah Dasar Negeri (SDN), dua diantaranya berada di Dusun Tirisan. Selain itu, terdapat 3 SMP/MTs, yitu SMPN 1, MTs Nurul Huda, dan SMP Muhammadiyah. Mengenai fasilitas, di SD dan SMP sudah cukup memadai. Potensi kelembagaan dengan karakteristik peserta didika yang masih anakanak memiliki konsekuensi pendidikan di satu sisi dan pasar di sisi yang lain. Pada aspek pendidikan keberadaan wisata perdesaan dapat memberikan rasa kepercayaan diri dan kebanggaan anak pada desa di mana mereka tinggal. Di saat bersamaan rasa kepercayaan tersebut dapat dikembangkan kepada proses pemeliharaan dan pelindungan pada kegiatan kelestarian kearifan lokal perdesaan baik berup alam hayati maupun budaya yang dimiliki.

Demikian halnya pada aspek pasar di mana kegiatan yang melibatkan peserta anak usia dini maupun remaja memberikan efek psikologis yang luas. Dalam kegiatan anakanak tentu kehadiran orang tua dan kerabat menjadi saat kuat sebagaimana loyalitas dan soliditas dikalangan remaja yang bersifat komunal. Salah satu upaya yang dilakukan adalah dengan lomba mewarnai tingkat TK Se-Kecamatan Pule. Kedua hal tersebut menjadi strategi untuk megembangkan kegiatan ekowisata yang menyasar pada kedua kelompok tersebut. Dampak positifnya strategi tersebut akan mampu menciptakan keramaian dan pasar sehinggga terjadi transaksi jual beli sehingga kegiatan ekonomi masyarakat desa Pule dapat berjalan.

\section{Strategi Penguatan Ekonomi UMKM sebagai Strategi Pasar Wisata di Desa Pule}

Bagian penting dari rangkaian strategi peningkatan ekonomi masyarakat di Desa Pule adalah dengan melaksanakan kegiatan Workshop Pengembangan UMKM Melalui Online Single Submission (OSS), dengan mengusung slogan "UMKM Obah Masyarakat Munggah". Acara tersebut berlangsung di Pendopo Kecamatan. Kegiatan ini diselenggarakan atas dasar banyaknya pelaku usaha mikro di wilayah Pule, tapi hingga saat ini hanya berkisar empat puluh lima pelaku usaha yang memproses perizinan UMKM. Pelaku usaha akan berbondong-bondong melakukan perizinan saat mereka membutuhkan pinjaman uang untuk mengembangkan usaha mereka. Terlepas dari itu, mereka akan cenderung tidak memproses perizinan tersebut.

Dengan mengusung slogan "UMKM Obah, Ekonomi Masyarakat Munggah", acara tersebut bekerjasama dengan beberapa pihak, diantaranya: Kecamatan Pule, Dinas Penanaman Modal Pelayanan Terpadu Satu Pintu (PMPTSP), IPNU-IPPNU, dan Mahasiswa KKN RM Se-kecamatan Pule. Harapan dengan adanya kerjasama ini, semua pelaku usaha di Kecamatan Pule mempunyai Izin Usaha Mikro (IUM). Dengan adanya IUM, usaha mereka lebih terawasi dan pelaku usaha mampu mengembangkan usaha mereka.

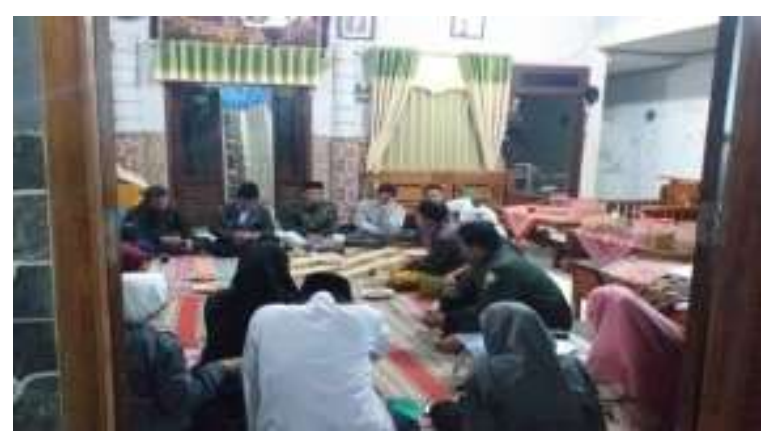

Gambar 1: Musyawarah dan sosialisasi wisata desa Pule 


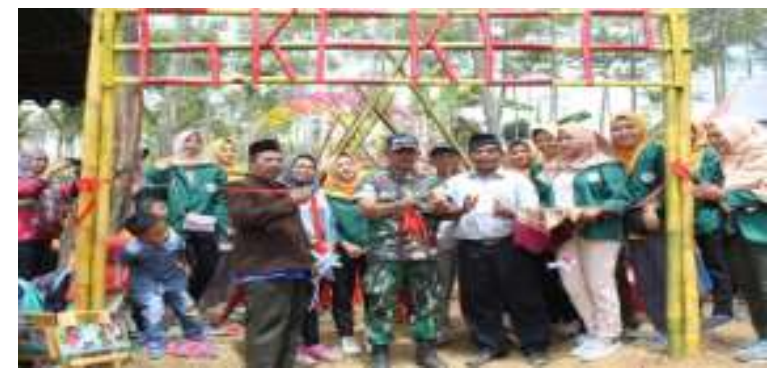

Gambar2: Peresmian wisata desa Pule

\section{Kesimpulan}

Wisata perdesaan memiliki pengaruh positif terhadap pemberdayaan ekonomi masyarakat sekaligus upaya membangun karakter cinta tanah air. Sebagai hasilnya pembentukan desa perdesaan desa Pule memiliki dua tujuan utama yakni pertama untuk meningkatkan usaha ekonomi alternative dan keberlanjutan serta mampu menekan pengiriman tenaga kerja Indonesia ke luar negeri yang dominan dilakukan masyarakat perdesaan. Kedua, keberadaan ekowisata merupakan bukti wujud kecintaan pada asal usul dan tempat lahir yang terimplementasikan melalui kesadaran konservasi alam melalui kegiatan pendidikan dan pembelajaran yang berbasis pada alam.

Sebagai rekomendasi perlu pendampingan keberlanjutan dari pihak desa dan pemerintahan serta meningkatkan kerjasa sama lembaga perguruan tinggi untuk memanfaatkan kegiatan KKN dalam meningkatkan kreatifitas dan inovasi pengembangan desa wisata yang marketable. Dengan demikian ekosistem dapat berjalan seimbang melalui kelestarian alam yang terus terjaga, ekonomi yang berkembang serta pendidikan konservasi dapat tertanam sejak anak berusia dini.

\section{DAFTAR REFERENSI}

Ardhana, I. P. G. (2018). Evaluasi Perkembangan Kegiatan Ekowisata di Areal Kawasan Hutan. Prosiding Seminar Nasional Pendidikan Biologi, 521-528.

Budiono, A. (2019). Teori Utilitarianisme Dan Perlindungan Hukum Lahan Pertanian Dari
Alih Fungsi. Jurnal Jurisprudence, 9(1), 102116. https:// doi.org/10.23917/jjr.v9i1.8294 Hermawan, H. (2016). Dampak Pengembangan Desa Wisata Nglanggeran Terhadap Ekonomi Masyarakat Lokal. Jurnal Pariwisata, 3(2), 105-117.

Hermawan, H., Brahmanto, E., \& Priyanto, R. (2018). Upaya Mewujudkan Wisata Edukasi di Kampung Tulip Bandung. JURNAL ABDIMAS BSI : Jurnal Pengabdian Kepada Masyarakat, 1(1), 45-54.

Kesuma, A. I. (2016). Membangun Ekowisata dan Ekonomi Kreatif Berbasis Masyarakat dan Kearifan Lokal dalam Menghadapi Masyarakat Ekonomi ASEAN. Prosiding Seminar Nasional, 02, 2-12.

Kindon, S., Pain, R., \& Kesby, M. (2007). Participatory Action Research Approaches and Methods; Connecting people, participation and place (1st ed.). London and New York: Routledge. https://doi.org/10.1017/CBO978110741532 4.004

Muntasib, E. K. S. H. (2018). Konsep dan Implementasi Pengembangan Ekowisata dalam Dunia Pendidikan. Prosiding Seminar Nasional Pendidikan Biologi, 505-511.

Nazarullail, F., Hardika, \& Desyanty, E. S. (2017). Pemberdayaan Masyarakat Melalui Program Ekowisata "Lepen Adventure." Jurnal Pendidikan Teori, Penelitian, Dan Pengembangan, 2(8), 1071-1076. Retrieved from https:/ / media.neliti.com/media/publicatio ns/210144-none.pdf

Pattiwael, M. (2018). Konsep Pengembangan Ekowisata Berbasisi Konservasi di Kampung Malagufuk Kabupaten Sorong. Journal of Education to Papua Community, 1(1), 42-54.

Rini, R., Setyobudiandi, I., \& Kamal, M. (2018). Kajian Kesesuaian, Daya Dukung dan Aktivitas Ekowisata di Kawasan Mangrove Lantebung Kota Makassar. Jurnal Pariwisata, 5(1), 1-10.

https://doi.org/10.31311/par.v5i1.3179

Safii, I., Fatih, A., Rosyid, A. A., Zamroni, M. A., 
\& Asy'ari, H. (2020). Pemberdayaan Desa Wisata Melalui Pengembangan Wisata Air Terjun Songgo Tuyo di Desa Nogosari Kec. Pacet Kabupaten Mojokerto. Engagement: Jurnal Pengabdian Kepada Masyarakat, 4(1), 138-155.

https://doi.org/10.29062/engagement.v4i1 .144

Sukiyono, K., Novanda, R. R., Priyono, B. S., Widiono, S., Arianti, N. N., Yuliarso, M. Z., ... Jannah, M. (2019). Inovasi Desa Membangun: Pemanfaatan Data IDM. Jakarta: Kementrian Desa, Pembangunan Daerah Tertinggal dan Transmigrasi Republik Indonesia. 